\title{
The HYP-RT Hypoxic Tumour Radiotherapy Algorithm and Accelerated Repopulation Dose per Fraction Study
}

\author{
W. M. Harriss-Phillips, ${ }^{1,2}$ E. Bezak, ${ }^{1,2}$ and E. Yeoh ${ }^{1,3}$ \\ ${ }^{1}$ School of Chemistry and Physics, University of Adelaide, Adelaide, SA 5005, Australia \\ ${ }^{2}$ Department of Medical Physics, Royal Adelaide Hospital, Adelaide, SA 5000, Australia \\ ${ }^{3}$ Department of Radiation Oncology, Royal Adelaide Hospital, Adelaide, SA 5000, Australia
}

Correspondence should be addressed to W. M. Harriss-Phillips, wendy.harriss@health.sa.gov.au

Received 16 February 2012; Accepted 11 April 2012

Academic Editor: Loredana Marcu

Copyright (c) 2012 W. M. Harriss-Phillips et al. This is an open access article distributed under the Creative Commons Attribution License, which permits unrestricted use, distribution, and reproduction in any medium, provided the original work is properly cited.

The HYP-RT model simulates hypoxic tumour growth for head and neck cancer as well as radiotherapy and the effects of accelerated repopulation and reoxygenation. This report outlines algorithm design, parameterisation and the impact of accelerated repopulation on the increase in dose/fraction needed to control the extra cell propagation during accelerated repopulation. Cell kill probabilities are based on Linear Quadratic theory, with oxygenation levels and proliferative capacity influencing cell death. Hypoxia is modelled through oxygen level allocation based on $\mathrm{pO}_{2}$ histograms. Accelerated repopulation is modelled by increasing the stem cell symmetrical division probability, while the process of reoxygenation utilises randomised $\mathrm{pO}_{2}$ increments to the cell population after each treatment fraction. Propagation of $10^{8}$ tumour cells requires 5-30 minutes. Controlling the extra cell growth induced by accelerated repopulation requires a dose/fraction increase of $0.5-1.0 \mathrm{~Gy}$, in agreement with published reports. The average reoxygenation $\mathrm{pO}_{2}$ increment of $3 \mathrm{mmHg}$ per fraction results in full tumour reoxygenation after shrinkage to approximately $1 \mathrm{~mm}$. HYP-RT is a computationally efficient model simulating tumour growth and radiotherapy, incorporating accelerated repopulation and reoxygenation. It may be used to explore cell kill outcomes during radiotherapy while varying key radiobiological and tumour specific parameters, such as the degree of hypoxia.

\section{Introduction}

Multiple studies have shown that hypoxia decreases cellular sensitivity to ionising radiation in living tissue. Consequently, there is an increase in radioresistance of hypoxic tumour cells following single or multifraction radiotherapy compared to oxic cells. Approximately $70 \%$ of locally advanced head and neck squamous cell carcinomas (HNSCC) have been reported to exhibit hypoxic regions, with median oxygen levels having a significant influence patient prognosis [1-3]. Reports from HNSCC clinical trials and experimental work commonly express hypoxia as the percentage of cells in the tumour having $\mathrm{pO}_{2}$ values less than 10,5 , or $2.5 \mathrm{mmHg}$, which is often very high $(>50 \%)[4,5]$. In contrast, the average $\mathrm{pO}_{2}$ for healthy epithelial cells is approximately $40 \mathrm{mmHg}$ [5].
Tumour hypoxia occurs when the diffusion of oxygen from the surrounding tissue becomes insufficient in a nonvascularised tumour mass. It has been shown that tumours can grow up to a diameter of 1 to $2 \mathrm{~mm}$ without an independent blood supply $[6,7]$, after which neovascularisation is necessary for sustained growth. However, the new blood vessels may be chaotic in nature and possess faults such as holes and shunts. Consequently, an unstable and insufficient oxygen supply may develop causing tumour hypoxia. However, when a tumour is treated with fractionated radiotherapy, oxygen levels may begin to increase again during the process of tumour shrinkage, a phenomenon named reoxygenation (ROx).

In aggressive tumours of epithelial origin such as HNSCC, cellular repopulation after trauma such high-dose irradiation, occurs through cell division of the surviving cell 
population. This repopulation can occur at an increased rate, a phenomenon named accelerated repopulation (AR). AR can have a detrimental impact on radiotherapy outcome, especially if the total treatment time is relatively long [8]. Multiple published HNSCC clinical trial reports conclude that the onset time of AR, or the so-called kick-off time, is between 2 and 5 weeks [8-12] after the start of treatment.

As a supplement to clinical trials, Monte Carlo (MC) models can provide treatment response predictions which are (i) readily obtained and low in cost, (ii) reproducible, (iii) have the ability to account for the statistical nature of cellular kinetics and radiotherapy physics, and (iv) tumour specific depending on the data input into the model. MC methods and modern computing technology now make it possible to simulate the progression of individual tumour cells throughout the growth and treatment of a tumour approaching clinical sizes.

The first reported computer model to employ MC methods was named CELLSIM by Donaghey and coworkers, published in the early 1980s [13]. One of the first models to include cellular-based stochastic methods as well as oxygen and nutrient diffusion factors came from work led by Dutching in the early 1980s and into the following decade [14-17]. Using their approach, a tumour up to $1 \mathrm{~mm}$ in diameter could be simulated and then treated with radiotherapy. Recent reports regarding stochastic hypoxic tumour modelling over that past two decades have come from work by group leaders such as Kocher, Titz, Borkenstein, and Stamatakos [18-24], in which the modelling of individual cells and hypoxia-related parameters have been applied.

The HYP-RT model reported on here is based on the biological proliferative hierarchy of epithelial tissue to simulate oxic as well as hypoxic head and neck squamous cell carcinoma evolution. Cell division is tracked throughout growth and fractionated radiotherapy. HYP-RT takes into account the reoxygenation process of hypoxic tumours and the increased proliferation caused by accelerated repopulation. Stem cell symmetrical division is applied as the sole mechanism of AR, that is, the division of a stem cell into two daughter stem cells, based on reports of the dominance of this mechanism over other mechanisms such as cell cycle time shortening $[8,25]$. A nonspatial approach in this probabilistic model means that cells are considered randomly placed within the tumour which is a justified approach considering that hypoxic tumour cells have been shown in multiple studies to be spatially irregular down to the submillimeter level, for example, in immunohistochemistry studies [26]. Compared to other models in the literature, HYP-RT has the benefits of fast computation, a high cell number, simple oxygenation data input in the form of a $\mathrm{pO}_{2}$ histogram, and the simulation of the combined effects of AR and ROx.

The aim of the current modelling work was to extend the previous hypoxic tumour growth algorithm [27] and simulate conventionally fractionated radiotherapy. Improving the cell data storage and random cell selection aspects of the algorithm was also a goal, so that a full simulation could be completed in less than one hour. It was also important to model a sufficient cell number to surpass the approximate avascular exponential growth phase $\left(10^{6}\right.$ cells $\left.[28]\right)$ and reach a cell number approaching clinical levels, that is, $10^{8}-10^{9}$ cells, while achieving statistically stable results $(\leq 5 \%)$.

This report outlines the methodology of the radiotherapy effect algorithm and discusses the key parameters of the model. Focus is placed on the $\mathrm{ROx}$ and $\mathrm{AR}$ modules of the algorithm and the effects of varying related parameters during simulations. The model is validated for the oxic tumour case through a comparison with linear quadratic (LQ) theory. The current work builds on a previous detailed description of the original hypoxic tumour growth algorithm [27] and the recently published conventional radiotherapy model outcomes [29] using the default parameters defined in the current report. In the following sections, modelling methods and algorithm design are detailed, along with the validation of modelling AR by means of increasing the stem cell symmetrical division probability and the consequential rise in dose per fraction needed to control the extra cell growth.

\section{Methods}

2.1. The Tumour Growth Algorithm. Carcinogenesis is initiated through cell division of a single oxic stem cell. Cell proliferation and subsequent tumour progression have been modelled by the continual division of cells into one or two viable daughter cells, with attributes allocated and saved to computer memory in an object vector array referred to as the cellarray The current data storage method differs from the two dimensional array methods previously reported. Methods were modified to allow for more efficient data storage that is $100 \%$ memory efficient at the time of tumour growth completion and enhanced efficiency relating to random sampling procedures.

In the model, each element in the cellarray represents one cell object containing all cellular attributes as well as a pointer value indicating the position of the next chronological cell due to divide (the linked list method). MC methods are implemented to allow the random nature of the cellular kinetics and the effects of radiation treatment to be simulated using probability distributions. Cellular parameters, such as cell cycle time (CCT) and the cell type, resulting from mother cell division and the differentiation process, are allocated based on random number generation using uniform, normal, or exponential probability distributions and the Ziggurat random number generator [36].

Stem cells $(S)$ first pass through the G0 quiescence phase with an exponential probability of duration and then enter the cell cycle. These cells are considered clonogenic and infinitely proliferating; however they may differentiate upon division or enter state of quiescence induced by low oxygenation. Other types of cells in the model include transit amplifying cells that cycle for a limited number of generations ( $T$ cells), differentiating cells ( $D 1$ and D2 cells), as well as fully differentiated cells (D3 cells). Stem cells may divide into $S, T$, or $D 1$ cells, while transit cells may divide into $D 1$ or $D 2$ cells. In normal epithelium, the D1 cells correspond to those created in the basal layer, while D2 to those created 
TABLE 1: Default parameter values and ranges available in the tumour growth algorithm.

\begin{tabular}{|c|c|c|c|}
\hline Parameter & Default & References & Comments \\
\hline Cell total & $10^{8}$ & N/A & The fully grown tumour cell limit. \\
\hline $\begin{array}{l}\text { Spercent, symmetrical stem cell division } \\
\text { probability }(\%)\end{array}$ & $3 \%$ & N/A & $\begin{array}{l}\text { This parameter was set to produce a } 1 \% \text { total stem } \\
\text { cell population in the tumour. }\end{array}$ \\
\hline $\begin{array}{l}\text { Low oxygen limit for cell cycle arrest } \\
(\mathrm{mmHg})\end{array}$ & $1 \mathrm{mmHg}$ & {$[43,44]$} & $\begin{array}{l}\text { At this } \mathrm{pO}_{2} \text { level hypoxia-induced quiescence may } \\
\text { be initiated. }\end{array}$ \\
\hline $\begin{array}{l}\text { Percentage of cells exiting the cell cycle } \\
\left.\text { (with } \mathrm{pO}_{2}<1 \mathrm{mmHg}\right)(\%)\end{array}$ & $50 \%$ & N/A & $\begin{array}{l}\text { The total number of hypoxia-induced quiescent } \\
\text { cells }(<1 \mathrm{mmHg})=3 \% \text { using this parameter } \\
\text { value, in line with the } \mathrm{pO}_{2} \text { histogram used. }\end{array}$ \\
\hline $\begin{array}{l}\text { Tumour cell number threshold for } \\
\text { hypoxia }\end{array}$ & $10^{6}$ & {$[6,7,28,45]$} & $\begin{array}{l}\text { Hypoxia is modelled after the cell number is } \\
\text { reached by allocating } \mathrm{pO}_{2} \text { from the modelled } \mathrm{pO}_{2} \\
\text { histogram. }\end{array}$ \\
\hline $\begin{array}{l}\text { Hypoxic cell half life due to necrosis: } \\
\mathrm{pO}_{2}<1 \mathrm{mmHg} \text { (days) }\end{array}$ & 4 days & {$[46,47]$} & $\begin{array}{l}\text { Due to the } 4 \text { - to } 10 \text {-day hypoxic cell lifetime in } \\
\text { human colon carcinoma spheroids, and } 2 \text { days in } \\
\text { xenograft HNSCC. }\end{array}$ \\
\hline
\end{tabular}

above the basal layer. The percentages of each cell type in the model were verified as biologically plausible based on experiment epithelial tissue reports and other modelling studies [37-39].

The parameter Spercent controls symmetrical stem cell division and represents the probability of a stem cell dividing into two daughter stems cells. This parameter was assigned a default value of $3.0 \%$, which was based on achieving a total stem cell population of approximately 1\% [27], a differentiated cell population of approximately $85 \%[37,38]$, and an average tumour doubling time of 50 days [40]. Note that doubling times for tumour of differing oxygenation levels fell within a 35- to 65-day range.

Due to the high percentage $(85 \%)$ of noncycling cells required to ensure suitable tumour growth rates, the modelled tumours may be roughly equated to mid- to welldifferentiated HNSCC disease. This is in contrast to poorly differentiated tumours. However, this distinction is difficult to quantify. The modelling of tumours exhibiting specific levels of differentiation was not a goal of the current work, nor was the interplay between the number of differentiated cells and tumour oxygenation status.

The oxygenation of oxic tumours utilises a uniform $\mathrm{pO}_{2}$ distribution, ranging from 5 to $100 \mathrm{mmHg}$. These $\mathrm{pO}_{2}$ limits were set due to $5 \mathrm{mmHg}$ often being used in published clinical trial reports as a hypoxic threshold and due to $100 \mathrm{mmHg}$ [41] being the highest value measured experimentally in HNSCC Eppendorf studies. To model a biologically relevant range of tumour cell $\mathrm{pO}_{2}$ values for head and tumours, normalised data from Eppendorf studies [5, 41, 42] were implemented using a log-normal function and a random number algorithm written by J. Filliben (1982).

Tumour growth parameters values were set using biological data from the literature (e.g., oxygen distribution). If this was not possible, the model was used to explore the relative effects of certain parameters on other variables and parameters during the growth and treatment process (e.g., ROx increment size during radiotherapy). Key growthrelated parameters and associated references are presented in Table 1.
Table 2: Tumour oxygenation histogram data for the three modelled oxygenation levels, indicating the modelled percentage of cells in four commonly reported $\mathrm{pO}_{2}$ ranges.

\begin{tabular}{lccc}
\hline $\begin{array}{l}\text { pO } \\
(\mathrm{mmHg} \text { range }\end{array}$ & Oxic (\%) & $\begin{array}{c}\text { Moderately } \\
\text { hypoxic }(\%)\end{array}$ & $\begin{array}{c}\text { Severely hypoxic } \\
(\%)\end{array}$ \\
\hline 0 to 2 & 2.1 & 7.3 & 9.4 \\
0 to 5 & 5.2 & 22.1 & 33.2 \\
0 to 10 & 10.4 & 45.6 & 54.5 \\
0 to 20 & 20.8 & 65.4 & 69.6 \\
\hline
\end{tabular}

To implement tumour hypoxia, a $\mathrm{pO}_{2}$ probability distribution is used to allocate values to daughter cells. For a mother cell producing only one cell, the mother cell $\mathrm{pO}_{2}$ is passed to the daughter cell. When two daughter cells are generated, one cell is randomly chosen to retain the mother cell $\mathrm{pO}_{2}$ and the other receives a new $\mathrm{pO}_{2}$ value from the distribution.

The first hypoxic $\mathrm{pO}_{2}$ distribution modelled is named moderate hypoxia. A second $\mathrm{pO}_{2}$ distribution representing a tumour with more severe hypoxia is also modelled. The severe hypoxia $\mathrm{pO}_{2}$ distribution is generated to achieve a relatively high number of cells in the low $\mathrm{pO}_{2}$ range $(<10 \mathrm{mmHg})$ compared to moderate hypoxia and is tested in the model for the impact on tumour growth rate. Distributions with a higher ( $>3 \%)$ percentage of cells below $1 \mathrm{mmHg}$ result in tumours that are too hypoxic and result in tumour shrinkage instead of growth. Both $\mathrm{pO}_{2}$ distributions along with published data are shown in Figure 1(a). Numeric histogram data for published versus modelled percentages of cells in different $\mathrm{pO}_{2}$ ranges are presented in Figure 1(b) and Table 2.

Cellular $\mathrm{pO}_{2}$ influences CCT $[43,48]$, implemented using an exponential function to slow the cell cycle with decreasing $\mathrm{pO}_{2}$. To account for the effects cell quiescence due to very low oxygenation, a threshold value of $1.0 \mathrm{mmHg}$ is applied. These quiescent cells then die with a half life value of 4 days unless subsequently reoxygenated. As some cells have 


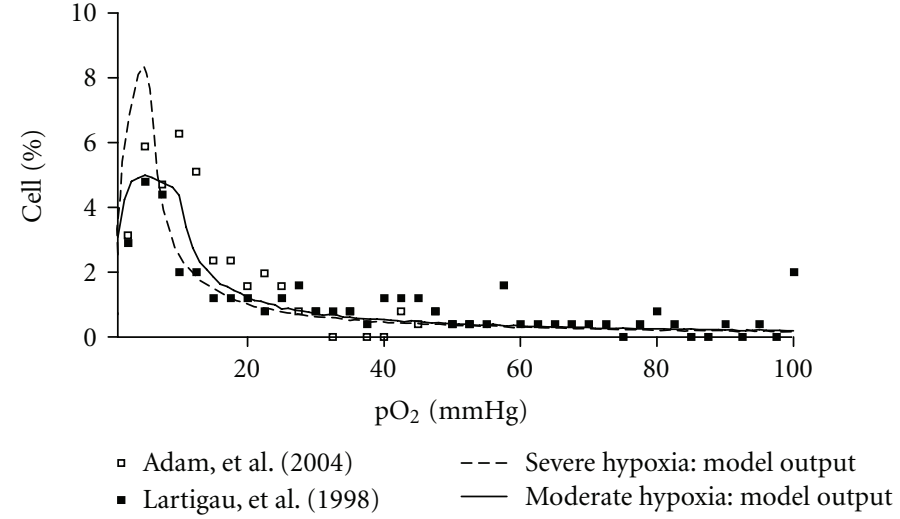

(a) Tumour oxygenation histrograms from the model and published data.
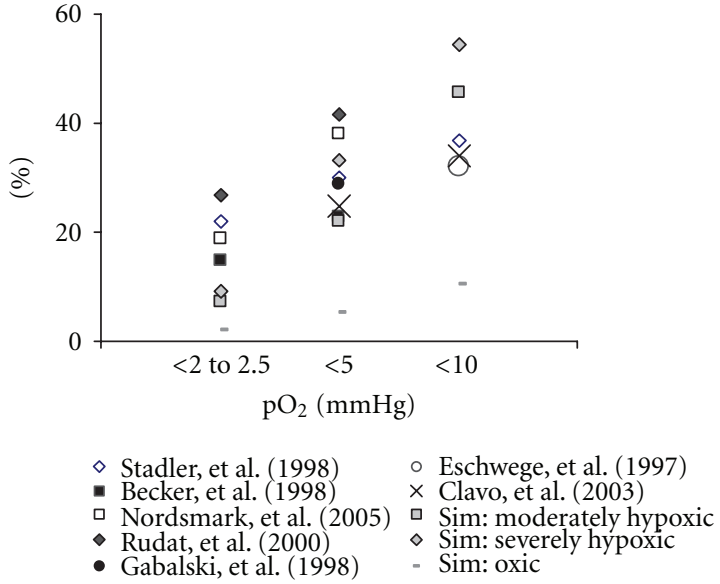

(b) Oxygenation Statistics in Human Head and Neck tumours.

Figure 1: The distribution of tumour oxygen levels used (a) to simulate moderate and severe tumour and (b) in simulations (sim) compared to published data for three oxygenation ranges [4,30-35]. The distributions in (a) represent the $\mathrm{pO}_{2}$ histogram outputs from the model using a log-normal random number generator.

been shown experimentally to continue cycling even at very low oxygenation levels through anaerobic metabolism, only a percentage of cells with $\mathrm{pO}_{2}$ of less than $1 \mathrm{mmHg}$ are made quiescent. The percentage for this parameter was determined by trial and error and ensuring that the total population of cells with this very low oxygenation corresponded with the log-normal $\mathrm{pO}_{2}$ distribution at the 0 to $1 \mathrm{mmHg}$ level (3\%).

An analysis of the growth algorithm was performed to analyse the effects of the symmetrical stem cell division probability (Spercent) on tumour growth rate (doubling time, $T_{D}$ ) and total growth time. This was carried out for oxic and hypoxic tumours, with the cell types in the population being validated. All of the current modelling work was programmed in the FORTRAN95 programming language within the Microsoft Visual Studio framework (2003).

2.2. The Radiotherapy Algorithm. The radiotherapy algorithm was developed to simulate the effects of fractionated therapy, assuming that a uniform dose is delivered to all cells. LQ theory is used to define the average cycling cell survival probability using the standard surviving fraction (SF) equation based on alpha and beta parameters. This is calculated for each cell individually for each dose fraction in the schedule. For example, using alpha and beta values of 0.3 and 0.03 , respectively $(\alpha / \beta=10 \mathrm{~Gy})$, and a standard $2 \mathrm{~Gy}$ per day treatment schedule, the SF value is $48.7 \%$. However, this calculation is adjusted for the individual cell based on the cellular $\mathrm{pO}_{2}$. The adjustment is based on the oxygen enhancement ratio (OER) (1), which is implemented in the program by normalising the OER curve to a maximum value of one at $60 \mathrm{mmHg}$ [49]:

$$
\text { OER }=\frac{1+0.81\left(\mathrm{pO}_{2}{ }^{0.616}\right)}{\left(1+0.324 \mathrm{pO}_{2}^{0.616}\right)}
$$

For each fraction, all cells in the cellarray are chronologically assessed to determine if they will survive or die. Figure 2 represents the relationship between (a) OER and $\mathrm{pO}_{2}(\mathrm{mmHg}$ ) and (b) probability of lethality and $\mathrm{pO}_{2}(\mathrm{mmHg})$ used in the model. Note that the effect of the actual dose being delivered is not shown in Figure 2, only the influence of $\mathrm{pO}_{2}$ on cell death when a specific dose per fraction is applied [50, 51].

To model the gradual rise in tumour oxygenation during treatment, $\mathrm{pO}_{2}$ increments $(3 \mathrm{mmHg})$ are distributed to the cell population at set time intervals. During reoxygenation events, a percentage of cells have their $\mathrm{pO}_{2}$ values increased by one or more $\mathrm{pO}_{2}$ increments, that is, by $0,3,6,9$, or $12 \mathrm{mmHg}$. Events are set to occur a few hours after each treatment fraction (default value of 4 hours [44]). The number of cells randomly chosen to receive the various increases in $\mathrm{pO}_{2}$ is based on Binomial theory (2):

$$
P_{k}=\left(\begin{array}{l}
n \\
k
\end{array}\right) p^{k}(1-p)^{n-k}
$$

where $n$ is the total number of oxygen increments (equal to the number of cells in the population at the current time), $k$ is the number of $\mathrm{pO}_{2}$ increments applied to a cell, and $P_{k}$ is the probability of a cell receiving a $k \times 3 \mathrm{mmHg}$ increase in $\mathrm{pO}_{2}$. The probability of five or more increments is below $0.5 \%$ and regarded as negligible.

Default parameters in the ROx algorithm were set through observation of the rate at which hypoxia-induced quiescent cells were brought back into the cell cycle and the rate of change of the resulting $\mathrm{pO}_{2}$ histograms from the cycling cell population. Oxygen increment size was set by default to ensure that tumours shrink to between $10^{5}$ and $10^{6}$ cells $\left(1 \mathrm{~mm}\right.$ in diameter) with a final $\mathrm{pO}_{2}$ histogram resembling a uniform oxic distribution with all $\mathrm{pO}_{2}$ values $\geq 5 \mathrm{mmHg}$.

Cells assigned to quiescence due to hypoxia $\left(\mathrm{pO}_{2}<\right.$ $1 \mathrm{mmHg}$ ) have a probability of having their $\mathrm{pO}_{2}$ levels 


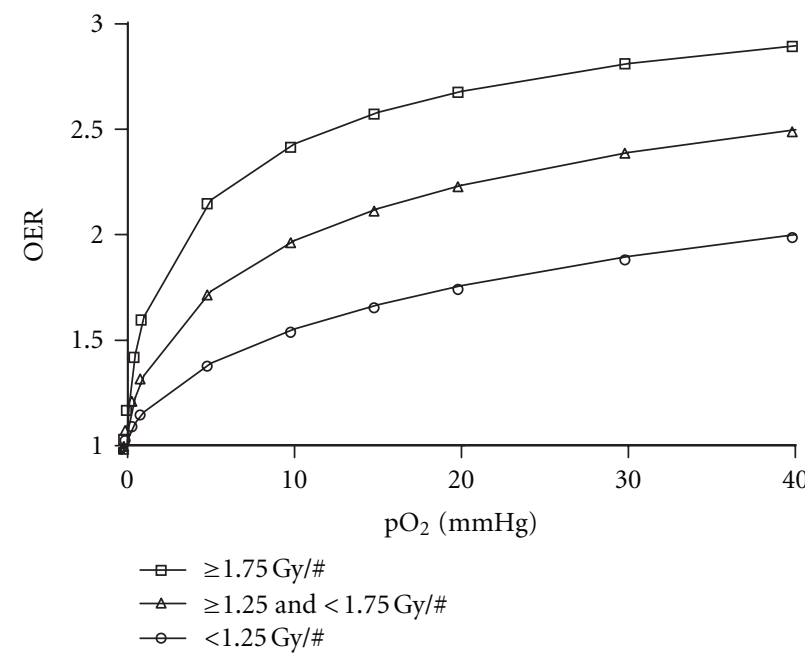

(a) Oxygen Enhancement ratio (OER) versus $\mathrm{pO}_{2}$ and dose per fraction.

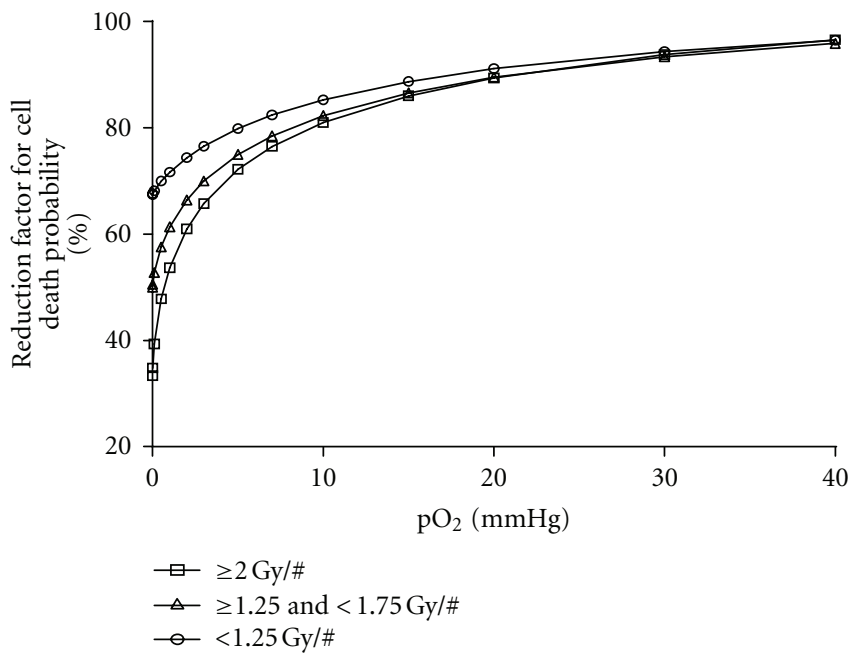

(b) The factor used to reduce the probability of cell death versus $\mathrm{pO}_{2}$ and dose per fraction.

FIgure 2: (a) Oxygen Enhancement Ratio (OER) curves implemented in the model for adjusting the radiosensitivity of cells during radiotherapy, based on cellular $\mathrm{pO}_{2}$ and dose per fraction, and (b) conversion of the OER curves into a probability of cell death factor, through OER curve normalisation.

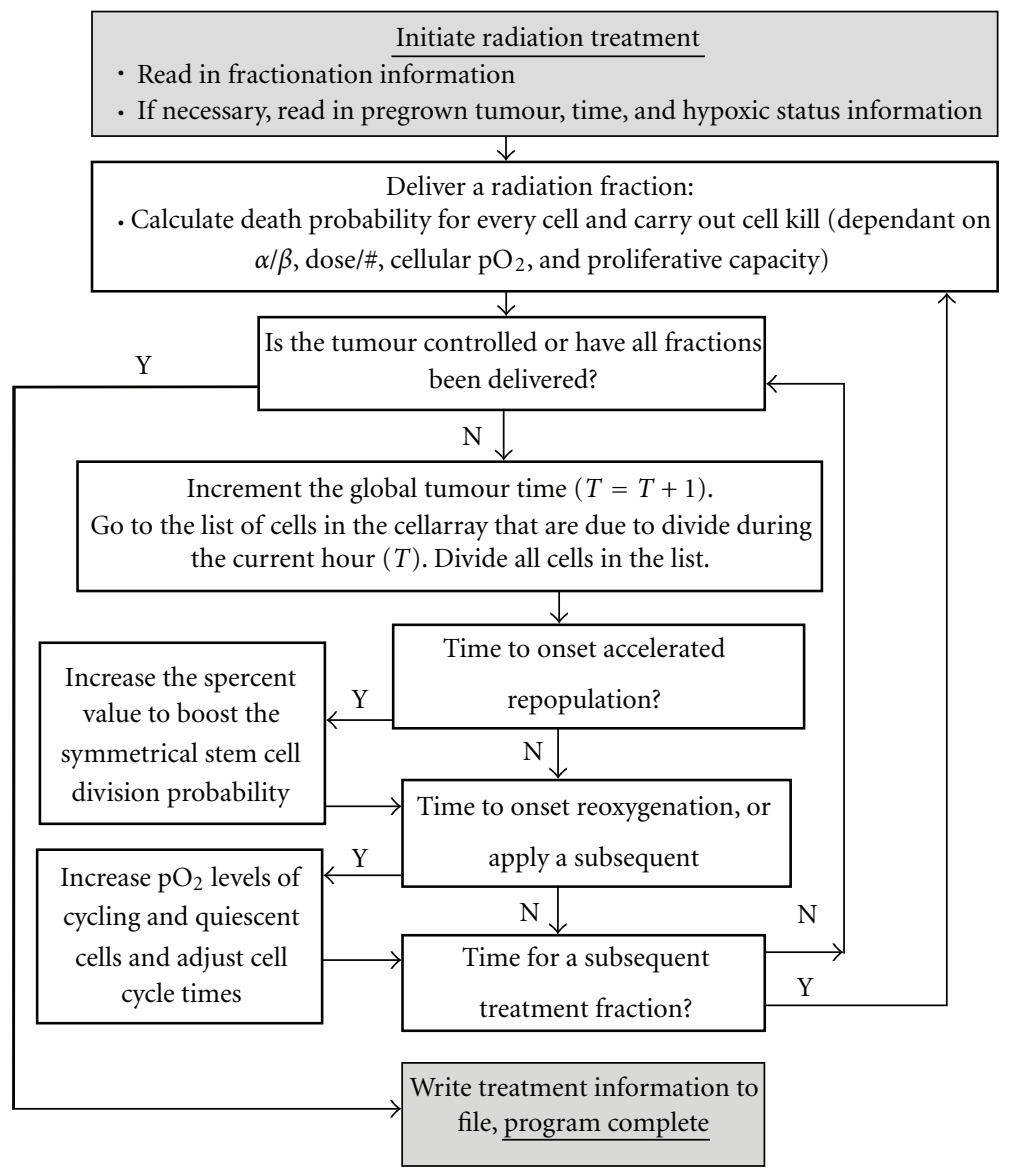

FIGURE 3: A flow diagram of the fractionated radiotherapy algorithm, where initiation of treatment is followed by continual cell proliferation between dose fractions. 
TABLE 3: A list of model parameters used in the fractionated radiotherapy algorithm.

\begin{tabular}{|c|c|c|c|}
\hline Parameter & Default & References & Comments \\
\hline $\begin{array}{l}\text { Accelerated repopulation (AR)-time of onset } \\
\text { after initialisation during RT (weeks) }\end{array}$ & No onset & {$[8,10-12,25,53-55]$} & $\begin{array}{l}\text { The number of weeks into RT that AR is } \\
\text { onset, 2-4 weeks observed in literature; } \\
\text { however } 0 \text { week onset has been made } \\
\text { possible for modelling microscopic response } \\
\text { in a small tumour system. }\end{array}$ \\
\hline $\begin{array}{l}\text { Reoxygenation (ROx)—time of onset after } \\
\text { initialisation during RT (weeks) }\end{array}$ & No onset & N/A & $\begin{array}{l}\text { An extremely variable parameter and open } \\
\text { to user input. }\end{array}$ \\
\hline $\begin{array}{l}\text { Time of ROx after a particular RT fraction } \\
\text { (weeks) }\end{array}$ & 4 hours & {$[44]$} & \\
\hline AR boost factor & $\times 10$ & {$[23,25,40]$} & $\begin{array}{l}\text { The factor applied to increase the } \\
\text { symmetrical stem cell division probability } \\
\text { during AR. }\end{array}$ \\
\hline $\begin{array}{l}\text { ROx-induced incremental increases in } \mathrm{pO}_{2} \\
(\mathrm{mmHg})\end{array}$ & $3 \mathrm{mmHg}$ & N/A & $\begin{array}{l}\text { The } \mathrm{pO}_{2} \text { increment size during randomised } \\
\text { reoxygenation after an } \mathrm{RT} \text { fraction (linearly } \\
\text { SF dependent), set to obtain full } \\
\text { oxygenation by } \sim 1 \text { to } 2 \mathrm{~mm} \text { tumour } \\
\text { diameter. }\end{array}$ \\
\hline $\begin{array}{l}\text { ROx percentage of the very low oxygenated cell } \\
\text { population }(\%)\end{array}$ & $60 \%$ & N/A & $\begin{array}{l}\text { The percentage of hypoxia-induced } \\
\text { quiescent cells brought back into the cell } \\
\text { cycle upon ROx after an RT fraction } \\
\text { (linearly SF dependent), set to obtain full } \\
\text { oxygenation when the tumour has reduced } \\
\text { to } 10^{5} \text { to } 10^{6} \text { cells (from } 10^{8} \text { initial cells). }\end{array}$ \\
\hline Alpha (LQ model) $\mathrm{Gy}^{-1}$ & 0.3 & {$[56,57]$} & $\begin{array}{l}\text { Used in SF calculations (linear quadratic } \\
\text { equation). }\end{array}$ \\
\hline Beta (LQ model) $\mathrm{Gy}^{-2}$ & 0.03 & & $\begin{array}{l}\text { Used in SF calculations (linear quadratic } \\
\text { equation). }\end{array}$ \\
\hline $\begin{array}{l}\text { Noncycling cell radiosensitivity compared to } \\
\text { oxic cycling cells }\end{array}$ & 0.5 & {$[58,59]$} & $\begin{array}{l}\text { Factor for the decreased radiosensitivity of } \\
\text { noncycling cells, based on the likely increase } \\
\text { in resistance of cells in resting phase (transit } \\
\text { cells and stems cells however assumed to be } \\
\text { equally radiosensitive in tumour cells). }\end{array}$ \\
\hline
\end{tabular}

increased using a parameter to control the percentage of cells to be retrieved from the quiescent group and reentered into the cellarray that stores the cycling cells.

Accelerated repopulation is modelled by increasing the Spercent variable by a multiplicative factor (the $A R$ boost factor) to simulate rapid tumour regrowth. As the range of possible onset times of AR varies in literature reports, a range of 0 to 3 weeks is analysed. This time range covers the possibility of immediate cell response as well as the latest onset time to have effect on total dose outcomes in the model.

The default $A R$ boost factor is based on a study of the extradose required to kill the cells that exist due to AR. When simulating no AR effects in oxic tumours $30 \times 2$ Gy $(6$ weeks of treatment) is required to control a tumour, therefore for all AR- and ROx-related simulations the effects of AR are calculated using 6 weeks at the iso-effect total treatment time. The duration of treatment for total cell kill was then compared to the 6-week standard time and the extradose per fraction required calculated for each simulation. Note that the extradose per fraction applies only during the weeks in which AR is occurring. The extra dose per fraction, $d$, is calculated using standard biological equivalent dose theory (3):

$$
\mathrm{BED}=n d\left(1+\frac{d \alpha}{\beta}\right)
$$

where BED is the total dose required from simulations to kill all cells after onset of $\mathrm{AR}, \alpha / \beta=10 \mathrm{~Gy}$, and $n$ is the number of fractions for which AR is applied [52]. The default irradiation schedule used in the treatment module for this work is the conventional 2 Gy per day, 5 day per week dose schedule. Figure 3 outlines the flow of the radiotherapy algorithm. The key parameters utilised in the model to simulate ROx and AR during radiotherapy are outlined in Table 3 . 


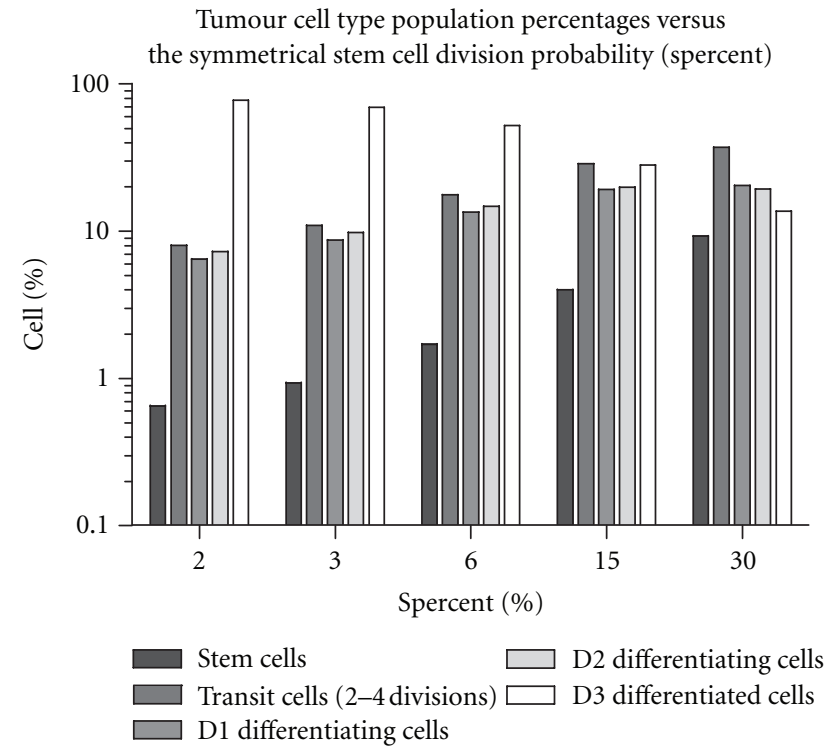

Figure 4: The average percentage of cell types within simulated tumours of $10^{8}$ cells, where (a) the symmetrical stem cell division probability parameter, Spercent, has been varied from 2 to $30 \%$ (standard deviation $<1 \%$ ).

\section{Results}

All tumour growth simulation results apply to $10^{8}$ cell virtual tumours. The results summarise the impact of the Spercent parameter on growth rate and cell types percentage and verify that the modelling of hypoxia does not change the cell population structure, as intended. Treatment results relate to verification of the default $A R$ boost factor for different AR onset times for both oxic and hypoxic tumours. Hypoxic tumour results are also presented for simulations varying the hypoxia-induced quiescent cell death half-life. Note that it may be possible for tumour cell of any proliferative capacity to avoid radiation cell kill due to hypoxia and become reoxygenated after treatment, contributing to local tumour recurrence. Moreover, hypoxia may cause mutations in the tumour cell population including dedifferentiation which may result in more aggressive tumour growth $[60,61]$. Consequently, although survival of only the stem cells is traditionally considered to result in treatment failure, the number of fractions required to kill all stem, transit, and first-generation differentiating cells is presented.

Hypoxic tumour radiotherapy results use the moderately hypoxic $\mathrm{pO}_{2}$ distribution shown in Figure 1(a). Severely hypoxic tumours with a higher number of cells in the 0 to $10 \mathrm{mmHg}$ range were also modelled, but results did not differ significantly from moderately hypoxic results. This issue will be investigated in future work to discern the necessary change in the shape of the $\mathrm{pO}_{2}$ curve (peak width and peak height) required to obtain statistically different outcomes for very hypoxic tumours.

3.1. Tumour Growth Analysis and Algorithm Efficiency. The constituent tumour cell population and the dependence of

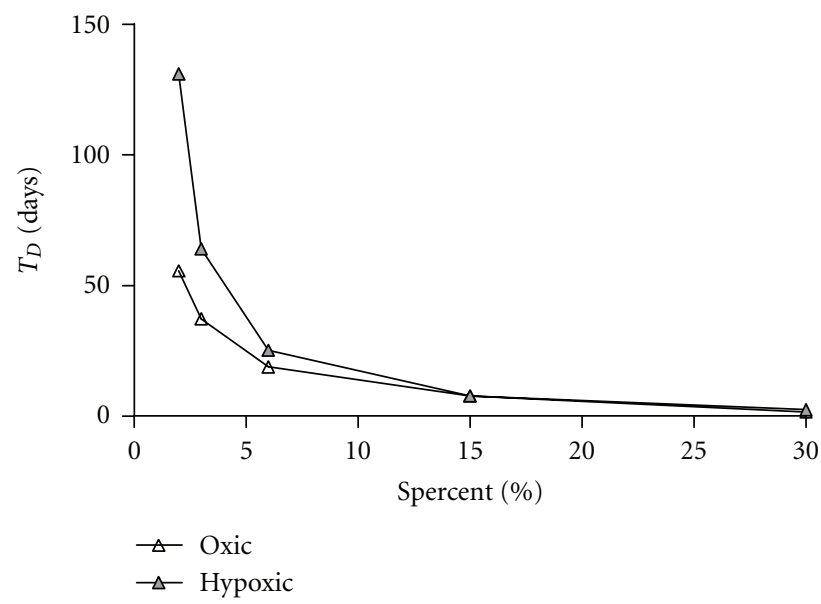

(a) Oxic vs. moderately hypoxic tumour doubling time $\left(T_{D}\right)$ versus the symmetrical stem cell division probability (Spercent).

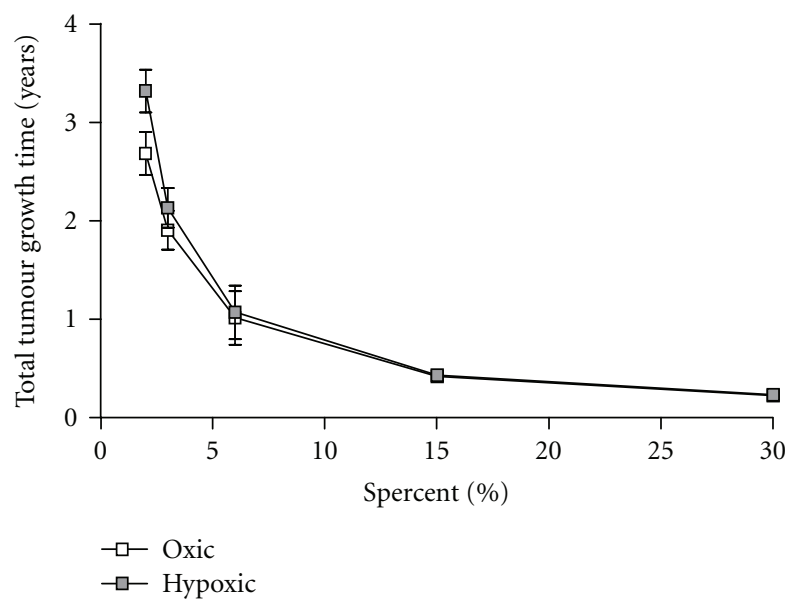

(b) Oxic vs. moderately hypoxic tumour total growth time $\left(10^{8}\right.$ cells $)$ versus the symmetrical stem cell division probability (Spercent).

FIgure 5: (a) The doubling time $\left(T_{D}\right)$, and (b) the total tumour growth times, versus the symmetrical stem cell division probability (Spercent) ranging from 2 to $30 \%$ for oxic and moderately hypoxic simulations of tumour growth up to $10^{8}$ cells. In Figure (a) the size of the error bars are negligible.

cell type percentage on the Spercent parameter are shown in Figure 4. The default value used for the Spercent parameter $(3 \%)$ results in a distribution of cell types that closely match literature reports and a realistic statistically stable tumour growth rate after $10^{4}$ cells $[38,40,62]$. The tumour growth characteristics for oxic and hypoxic tumours are displayed in Figures 5(a) and 5(b). These tumour growth times (for a small 0.5 to $1.0 \mathrm{~cm}$ diameter tumour mass) agree with reported values of $T_{D}$ for head and neck cancers [40]. Note that hypoxia-related parameters are set to maintain the distribution of cell types in the tumour throughout growth. Experimental data relating to how the cell percentages change when tumours are in a hypoxic state is difficult to obtain; therefore this effect has not been considered.

The linked list method of data storage allows for flexible and efficient cell data storage and enables $10^{8}$ cells to be 


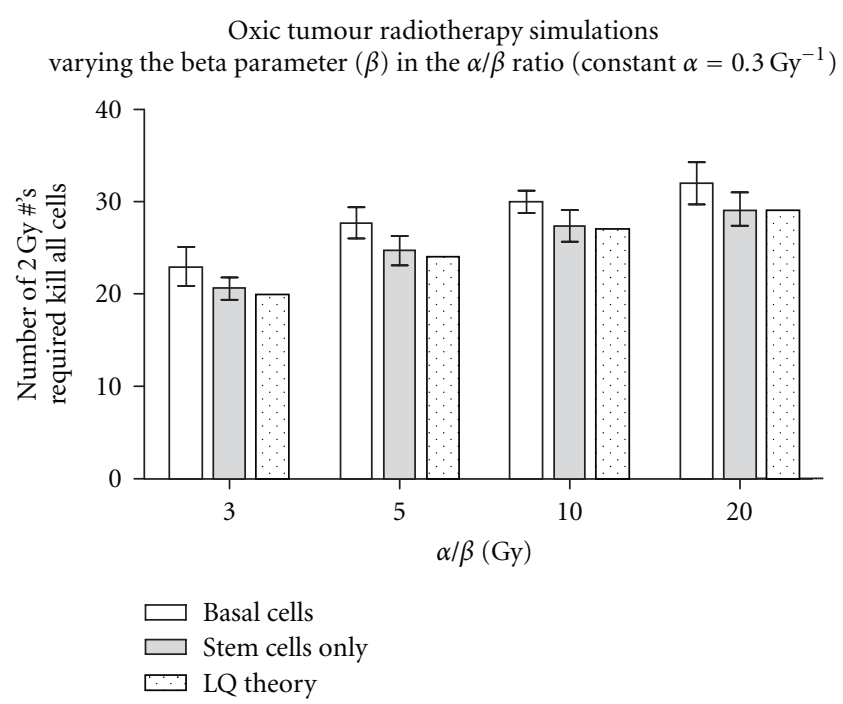

FIGURE 6: Comparison of the number of 2 Gy fractions required in the HYP-RT model to kill all basal or all stem cells compared to the linear quadratic (LQ) model (the first fraction that achieves $<1.000$ cells remaining), for oxic tumour conventional radiotherapy.

propagated on a standard off-the-shelf computer. For oxic tumour growth simulations the average computation time is now less than fifteen minutes. For hypoxic tumours this may be extended up to thirty minutes. Total tumour growth times increase for hypoxic tumours due to the extracell death and therefore a longer time was required to propagate cells up to an equivalent tumour volume. Treatment-related parameters, especially the Spercent and AR boost factor, also alter the computation time because of their impact on stem cell exponential growth and the reduction in (non-cycling ) cells.

3.2. The Dependence of Cell Kill on the Alpha/Beta Ratio. The default $\alpha / \beta$ value in the model is $10 \mathrm{~Gy}$. However, results for a range of $\alpha / \beta$ values help to verify that the model predicts the same level of cell kill as LQ theory for oxic tumours (Figure 6). In the comparison, $\alpha$ values were held constant $\left(0.3 \mathrm{~Gy}^{-1}\right)$ while the beta value was varied (from 0.1 to $0.015 \mathrm{~Gy}^{-2}$ ), producing $\alpha / \beta$ values in the range of 3 to $20 \mathrm{~Gy}$. For this analysis basal cell elimination as well as the elimination of stem cells only is considered. The stem cell simulation results are in good agreement with the LQ model, while results involving the cell kill of all basal cells are on average 2 to 3 fractions higher.

3.3. Oxic Tumour Radiotherapy. A factor is used in HYP-RT to increase the stem cell symmetrical division probability to model accelerated repopulation (the AR boost factor). To determine the most plausible AR boost factor, the onset times of $\mathrm{AR}$ are varied from $3 \%$ to $15 \%$ and from 0 to 3 weeks, respectively, and the consequential extra dose per fraction is required to account for the extracell growth calculated (Figure 7). Note that the increases in doses per fraction shown in Figure 7 apply during the period of AR only therefore the week of AR onset is not a critical parameter.

An $A R$ boost factor value of 10 results in an extra dose between 0.5 and $0.8 \mathrm{~Gy}$ per fraction, which is consistent with clinical trial reports $[8,63,64]$. An AR boost factor less than 10 increases the dose per fraction by $0.3 \mathrm{~Gy}$ or less, while an $A R$ boost factor more than 10 results in an extra dose per fraction above $1.0 \mathrm{~Gy}$. An AR boost factor of 10 was intuitively expected to impact on tumour response in a biologically plausible manner, as there have been reported increases in tumour growth rate of up to 10 times (reducing the potential doubling time $\left(T_{\text {pot }}\right)$ from approximately 10 to 20 days down to as low as 2 days $[8,65]$, approaching the stem cell division time.

An AR boost factor of 10 decreases the tumour doubling time after the onset of AR; for example, for moderately hypoxic tumours the tumour doubling time decreases from 65 days down to 4.4 days after the onset of AR. Similarly for oxic tumours, doubling times decrease from 37 days down to 3.7 days after the onset of AR (all standard deviation errors $<1$ day). For moderately hypoxic tumours these doubling times have good agreement with HNSCC published data [8].

3.4. Hypoxic Tumour Radiotherapy. Interfraction $\mathrm{pO}_{2}$ histograms for a reoxygenating tumour are shown in Figure 8. ROx events are initiated in simulations after the first dose fraction in this example, with full ROx occurring by fraction 11. The model smoothly moves the peak of the histogram curve to the right-hand side, to higher average $\mathrm{pO}_{2}$ levels, simulating gradual ROx in the tumour, as desired.

Cells exhibiting very low oxygenation $\left(\mathrm{pO}_{2}<1 \mathrm{mmHg}\right)$ levels enter a hypoxia-induced quiescent state. The modelled half-life of cells in this state does not impact significantly on the number of fractions required to control the tumour; however it does alter the timing of full ROx. Figure 9 shows the impact of the hypoxic cell half life on cell kill and full ROx timing when varied from 2 to 6 days.

The timing of ROx applied after completion of each fraction of conventional therapy was analysed for the impact on the total dose required to kill all cells. No significant difference was found between applying ROx either 4 or 23 hours (just preceding the next daily fraction) after a fraction. This result is expected since only conventional treatments were simulated in this study, with 24 hours between fractions. However, for future simulation work involving alternate schedules (hyperfractionated schedules with less than $2 \mathrm{~Gy}$ per fraction), this may change since ROx may occur during or after the next, same day fraction.

The effects of $\mathrm{AR}$ on the dose per fraction required to maintain total treatment times for hypoxic tumours were also studied. During these calculations, 8 weeks is used for the standard treatment time, as this is the treatment time required in hypoxic tumour simulations with no AR considered. The increase in dose per fraction (above the standard $2.0 \mathrm{~Gy}$ ) is 0.5 to $0.9 \mathrm{~Gy}$ using an $A R$ boost factor of 10 (Figure 10), closely matching oxic tumour results. The dose per fraction required during AR to control the extracell growth is relatively consistent for different AR onset times 


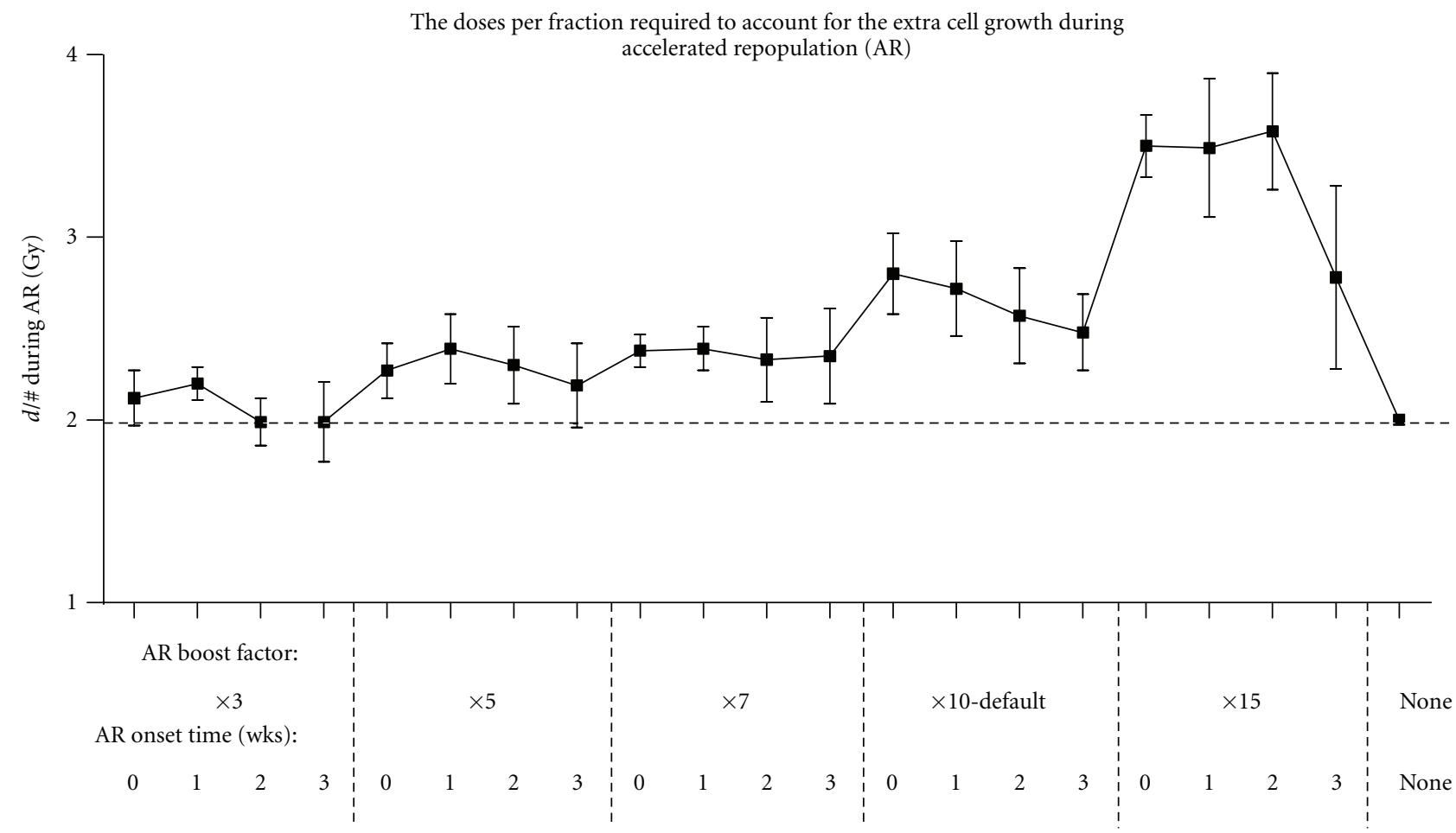

FIgURE 7: The increase in dose per fraction $(d / \#)$ required during conventional radiotherapy of oxic tumours to account for accelerated repopulation (AR), assuming a fixed total treatment time of 6 weeks and the increase in $d / \#$ coinciding with the onset of AR.

$\mathrm{pO}_{2}$ histograms immediately after reoxygenation $(\mathrm{ROx})$ for a tumour programmed to begin ROx after fraction 1 of radiotherapy (4-hour proceeding treatment)

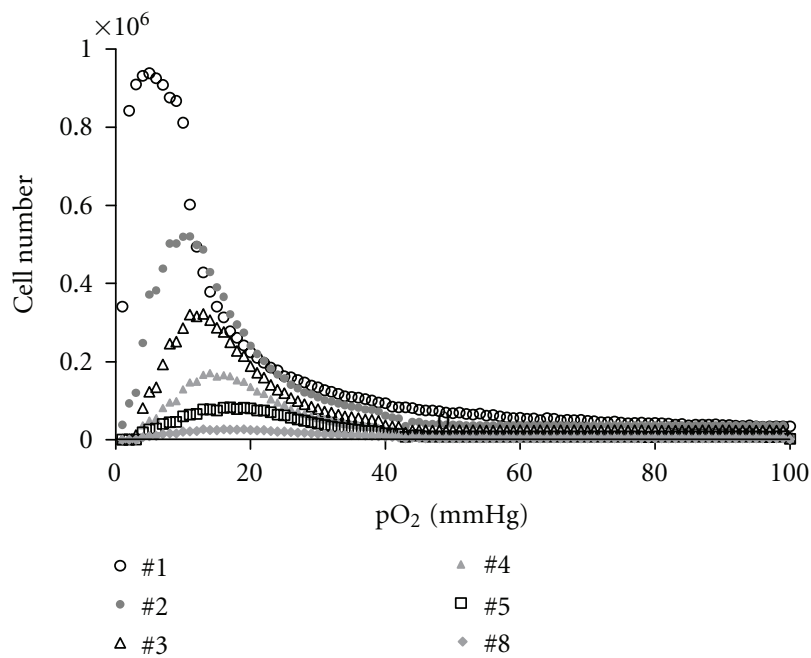

Figure 8: Oxygenation $\left(\mathrm{pO}_{2}\right)$ histograms after each fraction of simulated conventional radiotherapy, ranging from fractions 1 to 8 of a moderately hypoxic tumour. In this example, treatment is initiated when the tumour population has reached $10^{8}$ cells and hypoxic quiescent cells are reoxygenated above $1 \mathrm{mmHg}$ by fraction number $11\left(5 \times 10^{6}\right.$ cells $)$ and above $5 \mathrm{mmHg}$ by fraction $20\left(5 \times 10^{5}\right.$ cells). (as it is in the oxic tumour study), because the dose increase only applies after AR onset. With ROx simultaneously considered, the dose per fraction reduces slightly but is still approximately an extra 0.5 Gy per fraction.

An AR boost factor of 10 is considered the most valid value for this parameter based not only on the dose per fraction study but also according to the decrease in tumour doubling times predicted by the model; for example, the tumour doubling time reduced to 1 to 5 days after onset of AR compared with 35 to 65 days before onset of AR, with the range depending on oxygenation status.

These results also indicate that the onset time of AR is likely to be $\leq 2$ weeks if ROx occurs at $\leq 2$ weeks. However, the onset time of AR could be $>2$ weeks if ROx also occurs late or not at all (based on dose per fraction increases within 0.5 to $1.0 \mathrm{~Gy})$. Note that in all text and figures, error bars represent standard deviations based on nine simulations per parameter set. The statistical software package Prism 5 (v5.02, GraphPad Software Inc.) and Microsoft Excel 2003 were used in the analysis of the data.

\section{Discussion}

Onset times of ROx may be varied in the model from zero (immediately after treatment initiation) to three weeks. Immediate ROx is biologically possible because of the reduced demand of oxygen arising from the death of the 


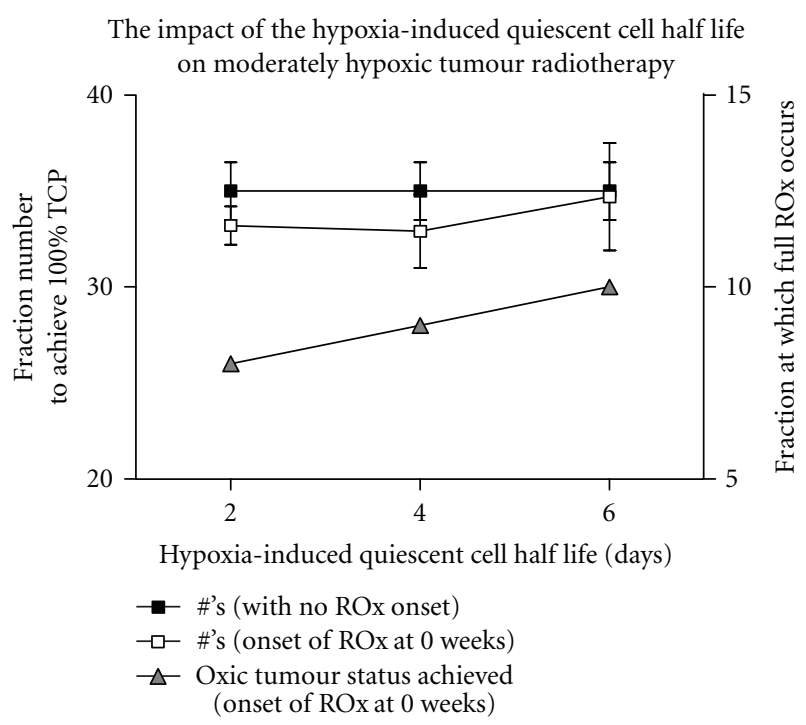

FIgURE 9: A comparison of the average number of conventional radiotherapy fractions with simulated reoxygenation (ROx) with no accelerated repopulation, required for cell kill of moderately hypoxic tumours when varying the half life of hypoxic quiescent cells.

first lethally hit cells (some hours after the first fraction). Variability of onset of ROx occurs because of other considerations such as the structure of the vascular and supporting tissues of the tumour and the dynamics of dead cell clearance from the tumour mass. All of these factors are likely to vary among patients, making the prediction of onset time of ROx for a particular tumour especially challenging. The timing of ROx events after each treatment fraction does not impact on the final cell kill results for the simulated conventional treatments in this study beyond the statistical error of the algorithm. The impact was not expected to be significant because all ROx events were programmed to occur before the next daily fraction.

ROx is ideally modelled continuously throughout tumour shrinkage. Modelling increases to cellular $\mathrm{pO}_{2}$ levels at every hour of the radiotherapy regimen is computationally exhaustive; therefore as a compromise, ROx events are modelled after every daily dose fraction. Ideally, modelling of ROx would also be based on human pre- and midtreatment tumour oxygenation assay or imaging data, for example, PET, CT, MRI, or US imaging methods; however such data is not readily available for every patient. In the future more data of this kind may become available through research efforts including stratification of patients in clinical trials investigating tumour oxygenation dynamics. Trial outcomes would be very useful for radiobiological modelling of tumour treatment response; however they may never be able to predict individual tumour oxygenation behavior for a specific patient. At this stage, the model can provide quantitative information about the relative importance of hypoxia and reoxygenation during radiotherapy. Results highlight the need to pursue research into techniques for noninvasively and efficiently collecting individual tumour data for input into oxygenation specific models.
Modelling the onset time of AR as early as zero weeks is based on the hypothesis that the microscopic response of tumour cell injury may start after the first radiative damage event. This somewhat contradicts reports based on clinical trial data of AR onset or kick-off times in the order of 2 to 5 weeks $[8,9,11,55,65]$. However, these reports are based on large patient averages of total treatment time effects and results of which are not necessarily representative of when $\mathrm{AR}$ is initiated at the microscopic level. Like ROx, AR onset times are likely to vary from patient to patient; thus for this study a range of onset times of 0 to 3 weeks is used.

Due to the complexity of biological factors required in the model, it was necessary to make a number of assumptions/limitations. The reduction of the cell cycle time as an AR mechanism has been shown to have a significant but relatively small effect on tumour response; however this was not modelled. It is likely that a number of these mechanisms are induced together and are more significant if used in combination $[8,25,65,66]$. Abortive division of sterilised stem cells (rather than differentiating) may also contribute to repopulation of tissue after irradiation [67]. However, these effects are not as well understood, with limited studies in the literature.

The radiotherapy effect algorithm does not take into account repair of radiation-induced cell damage; however the modelling of cellular repair will be considered in future work. Spatial information of the tumour cells was not taken into account; however this was not a hindrance to the current results which are concerned with homogeneous dose delivery. For future spatial dose delivery application, such as IMRT or dose painting, the modelling of specific hypoxic subvolumes of hypoxia will be a necessary addition to the model.

HYP-RT modelling methods vary from other recent stochastic hypoxia and radiotherapy modelling methods, involving individual cells or cell groups $[20,24,68]$, because the tumour oxygenation data required is simple and easily input in the form of a $\mathrm{pO}_{2}$ histogram. The $\mathrm{pO}_{2}$ histogram may also be manipulated during tumour growth (or treatment) if required to model dynamic oxygenation effects.

Current issues with this model and other models of this kind include the requirement of data gained through methods that are invasive for the patient; however this is improving as imaging techniques and associated marker drugs are being researched and trialled.

Possible current uses for the model include the study of cellar kinetic mechanisms and observations of (i) the relative differences in total doses required when $\mathrm{AR}$ and $\mathrm{ROx}$ are onset at various times, (ii) the differences in the total doses required for tumours of varying oxygenation levels, and (iii) the prediction of the effects of treatment breaks on the extradose required to compensate for the break.

\section{Conclusion}

Due to the complexities and dynamic nature of tumour oxygen and reoxygenation during radiotherapy, MC methods remain the most comprehensive and simplistic way of 


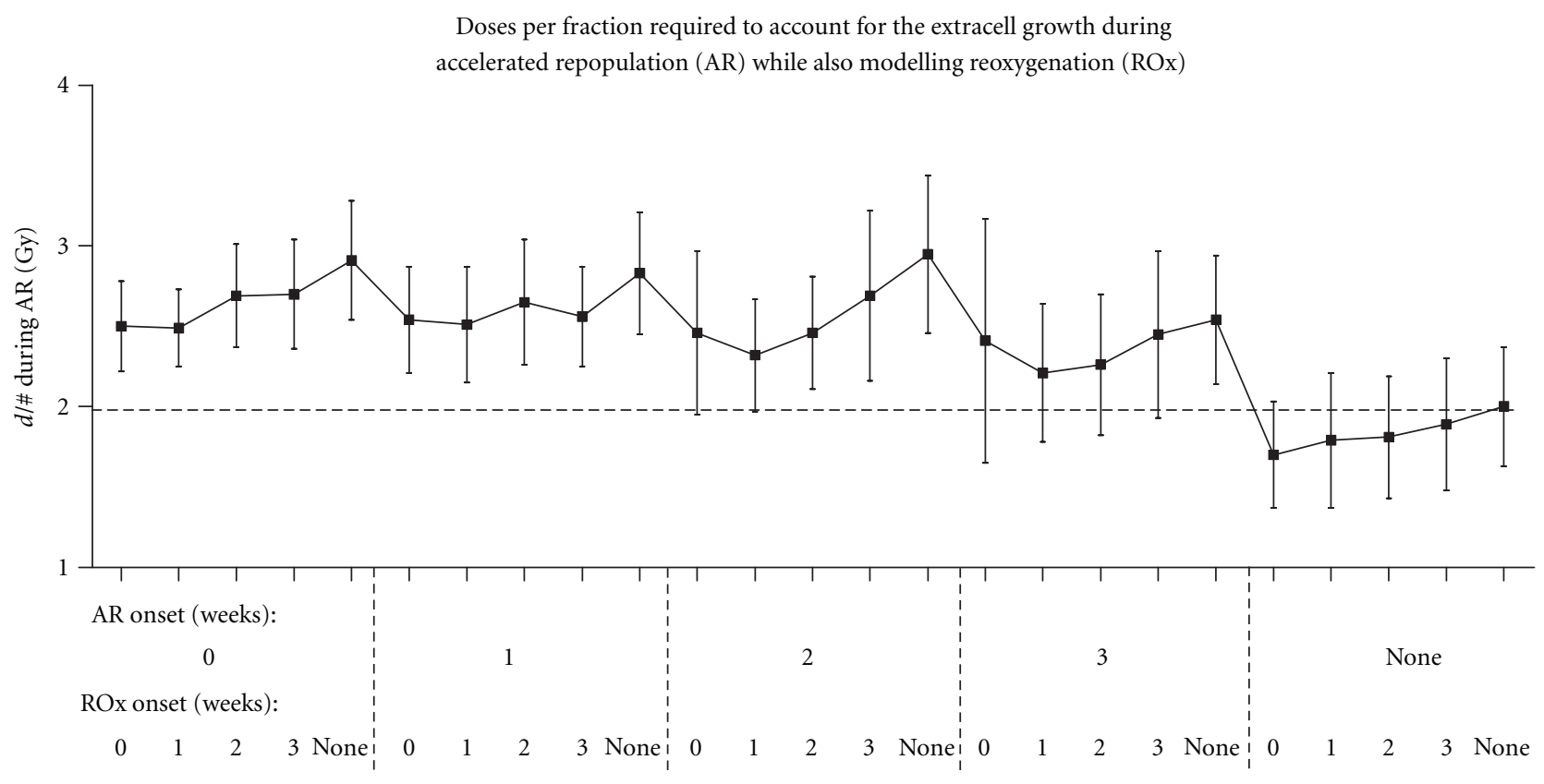

FIGURE 10: The increase in dose per fraction $(d / \#)$ required during conventional radiotherapy of moderately hypoxic tumours to account for accelerated repopulation (AR), assuming a fixed total treatment time of 8 weeks and the increase in $d / \#$ coinciding with the onset of AR, for various onset times of AR and ROx.

incorporating hypoxia into a tumour model. The HYP-RT model builds upon previous tumour growth modelling work and is capable of modelling radiation cell kill for tumours comprised of up to $10^{8}$ individual cells. Computational and temporal efficiency has been improved compared to previous model versions, with better use of memory space and more efficient selection and allocation of randomised parameters. Simulations of tumour growth and radiotherapy treatment can be performed in approximately thirty minutes or less. The way in which tumour hypoxia has been modelled is simple yet specific, enabling individual tumour data input in the form of a pretreatment $\mathrm{pO}_{2}$ histogram.

The reoxygenation algorithm provides a method of gradually altering the initially hypoxic tumour oxygenation histogram throughout treatment, to model the process of oxygenation increase for a hypoxic tumour. The accelerated repopulation algorithm provides a method of increasing the cell propagation rate, using a parameter that increases the symmetrical stem cell division probability, with a factor of ten found to be most suitable value based on a study involving the increase in dose per fraction required to the kill the extracell growth during conventional radiotherapy.

Future aims include efficiently modelling $10^{9}$ cell virtual tumours to provide an even larger individual cell-based model and the conversion of the code into the more modern $\mathrm{C}++$ programming language. The model has already been used to explore the conventional radiotherapy schedule for hypoxic tumours [29] and will be reported on in the near future regarding alternate radiation regimens for tumours of different oxygenation levels.

\section{Acknowledgments}

The authors would like to thank Dr. Loredana Marcu and Dr. Damien Phillips, for theoretical radiobiology and code development assistance during this work.

\section{References}

[1] D. M. Brizel, R. K. Dodge, R. W. Clough, and M. W. Dewhirst, "Oxygenation of head and neck cancer: changes during radiotherapy and impact on treatment outcome," Radiotherapy and Oncology, vol. 53, no. 2, pp. 113-117, 1999.

[2] M. Nordsmark and J. Overgaard, "Tumor hypoxia is independent of hemoglobin and prognostic for loco-regional tumor control after primary radiotherapy in advanced head and neck cancer," Acta Oncologica, vol. 43, no. 4, pp. 396-403, 2004.

[3] P. Stadler, A. Becker, H. J. Feldmann et al., "Influence of the hypoxic subvolume on the survival of patients with head and neck cancer," International Journal of Radiation Oncology Biology Physics, vol. 44, no. 4, pp. 749-754, 1999.

[4] M. Nordsmark, S. M. Bentzen, V. Rudat et al., "Prognostic value of tumor oxygenation in 397 head and neck tumors after primary radiation therapy. An international multi-center study," Radiotherapy and Oncology, vol. 77, no. 1, pp. 18-24, 2005.

[5] M. F. Adam, E. C. Gabalski, D. A. Bloch et al., "Tissue oxygen distribution in head and neck cancer patients," Head \& Neck, vol. 21, no. 2, pp. 146-53, 1999.

[6] C. J. Conti, "Vascular endothelial growth factor: regulation in the mouse skin carcinogenesis model and use in antiangiogenesis cancer therapy," Oncologist, vol. 7, supplement 3, pp. 4-11, 2002 . 
[7] J. A. Stanley, W. U. Shipley, and G. G. Steel, "Influence of tumour size on hypoxic fraction and therapeutic sensitivity of Lewis lung tumour," British Journal of Cancer, vol. 36, no. 1, pp. 105-113, 1977.

[8] H. R. Whithers, J. M. G. Taylor, and B. Maciejewski, "The hazard of accelerated tumor clonogen repopulation during radiotherapy," Acta Oncologica, vol. 27, no. 2, pp. 131-146, 1988.

[9] D. J. Brenner, "Accelerated repopulation during radiotherapy: quantitative evidence for delayed onset," Radiation Oncology Investigations, vol. 1, no. 3, pp. 167-172, 1993.

[10] B. Maciejewski, H. R. Withers, J. M. G. Taylor, and A. Hliniak, "Dose fractionation and regeneration in radiotherapy for cancer of the oral cavity and oropharynx: tumor dose-response and repopulation," International Journal of Radiation Oncology Biology Physics, vol. 16, no. 3, pp. 831-843, 1989.

[11] L. J. Peters and H. R. Withers, "Applying radiobiological principles to combined modality treatment of head and neck cancer-the time factor," International Journal of Radiation Oncology Biology Physics, vol. 39, no. 4, pp. 831-836, 1997.

[12] K. R. Trott, "The mechanisms of acceleration of repopulation in squamous epithelia during daily irradiation," Acta Oncologica, vol. 38, no. 2, pp. 153-157, 1999.

[13] C. E. Donaghey, "CELLSIM and CELLGROW: tools for cell kinetic modeling," ISA Transactions, vol. 22, no. 4, pp. 21-24, 1983.

[14] W. Duchting, T. Ginsberg, and W. Ulmer, "Modeling of radiogenic responses induced by fractionated irradiation in malignant and normal tissue," Stem Cells, vol. 13, supplement 1, pp. 301-306, 1995.

[15] W. Duchting, W. Ulmer, R. Lehrig, T. Ginsberg, and E. Dedeleit, "Computer simulation and modelling of tumor spheroid growth and their relevance for optimization of fractionated radiotherapy," Strahlentherapie und Onkologie, vol. 168, no. 6, pp. 354-360, 1992.

[16] W. Duechting and T. Vogelsaenger, "Three-dimensional pattern generation applied to spheroidal tumor growth in a nutrient medium," International Journal of Bio-Medical Computing, vol. 12 , no. 5, pp. 377-392, 1981.

[17] W. Duchting and Vogelsaenger Th., "Recent progress in modelling and simulation of three-dimensional tumor growth and treatment," BioSystems, vol. 18, no. 1, pp. 79-91, 1985.

[18] K. Borkenstein, S. Levegrün, and P. Peschke, "Modeling and computer simulations of tumor growth and tumor response to radiotherapy," Radiation Research, vol. 162, no. 1, pp. 7183, 2004.

[19] D. D. Dionysiou, G. S. Stamatakos, N. K. Uzunoglu, K. S. Nikita, and A. Marioli, "A four-dimensional simulation model of tumour response to radiotherapy in vivo: parametric validation considering radiosensitivity, genetic profile and fractionation," Journal of Theoretical Biology, vol. 230, no. 1, pp. $1-20,2004$.

[20] C. Harting, P. Peschke, K. Borkenstein, and C. P. Karger, "Single-cell-based computer simulation of the oxygen-dependent tumour response to irradiation," Physics in Medicine and Biology, vol. 52, no. 16, pp. 4775-4789, 2007.

[21] M. Kocher, H. Treuer, J. Voges, M. Hoevels, V. Sturm, and R. P. Müller, "Computer simulation of cytotoxic and vascular effects of radiosurgery in solid and necrotic brain metastases," Radiotherapy and Oncology, vol. 54, no. 2, pp. 149-156, 2000.

[22] G. S. Stamatakos, E. I. Zacharaki, M. I. Makropoulou et al., "Modeling tumor growth and irradiation response in vitro-a combination of high-performance computing and web-based technologies including VRML visualization," IEEE Transactions on Information Technology in Biomedicine, vol. 5, no. 4, pp. 279-289, 2001.

[23] L. Marcu, T. van Doorn, S. Zavgorodni, and I. Olver, "Growth of a virtual tumour using probabilistic methods of cell generation," Australasian Physical and Engineering Sciences in Medicine, vol. 25, no. 4, pp. 155-161, 2002.

[24] B. Titz and R. Jeraj, "An imaging-based tumour growth and treatment response model: investigating the effect of tumour oxygenation on radiation therapy response," Physics in Medicine and Biology, vol. 53, no. 17, pp. 4471-4488, 2008.

[25] L. Marcu, T. van Doorn, and I. Olver, "Modelling of postirradiation accelerated repopulation in squamous cell carcinomas," Physics in Medicine and Biology, vol. 49, no. 16, pp. 3767-3779, 2004.

[26] A. S. E. Ljungkvist, J. Bussink, J. H. A. M. Kaanders, N. E. Wiedenmann, R. Vlasman, and A. J. Van Der Kogel, "Dynamics of hypoxia, proliferation and apoptosis after irradiation in a murine tumor model," Radiation Research, vol. 165, no. 3, pp. 326-336, 2006.

[27] W. M. Tuckwell, E. K. Bezak, E. Yeoh, and L. Marcu, "Efficient Monte Carlo modelling of individual tumour cell propagation for hypoxic head and neck cancer," Physics in Medicine and Biology, vol. 53, no. 17, pp. 4489-4507, 2008.

[28] D. L. S. McElwain, R. Callcott, and L. E. Morris, "A model of vascular compression in solid tumours," Journal of Theoretical Biology, vol. 78, no. 3, pp. 405-415, 1979.

[29] W. M. Harriss-Phillips, E. Bezak, and E. K. Yeoh, "Monte Carlo radiotherapy simulations of accelerated repopulation and reoxygenation for hypoxic head and neck cancer," British Journal of Radiology, vol. 84, no. 1006, pp. 903-918, 2011.

[30] A. Becker, G. Hänsgen, M. Blocking, C. Weigel, C. Lautenschläger, and J. Dunst, "Oxygenation of squamous cell carcinoma of the head and neck: comparison of primary tumors, neck node metastases, and normal tissue," International Journal of Radiation Oncology Biology Physics, vol. 42, no. 1, pp. 35-41, 1998.

[31] B. Clavo, J. L. Pérez, L. López et al., "Influence of haemoglobin concentration and peripheral muscle $\mathrm{pO}_{2}$ on tumour oxygenation in advanced head and neck tumours," Radiotherapy and Oncology, vol. 66, no. 1, pp. 71-74, 2003.

[32] F. Eschwege, J. Bourhis, T. Girinski et al., "Predictive assays of radiation response in patients with head and neck squamous cell carcinoma: a review of the Institute Gustave Roussy experience," International Journal of Radiation Oncology Biology Physics, vol. 39, no. 4, pp. 849-853, 1997.

[33] E. C. Gabalski, M. Adam, H. Pinto, J. M. Brown, D. A. Bloch, and D. J. Terris, "Pretreatment and midtreatment measurement of Oxygen tension levels in head and neck cancers," Laryngoscope, vol. 108, no. 12, pp. 1856-1860, 1998.

[34] V. Rudat, B. Vanselow, P. Wollensack et al., "Repeatability and prognostic impact of the pretreatment $\mathrm{pO}_{2}$ histography in patients with advanced head and neck cancer," Radiotherapy and Oncology, vol. 57, no. 1, pp. 31-37, 2000.

[35] P. Stadler, H. J. Feldmann, C. Creighton, R. Kau, and M. Molls, "Changes in tumor oxygenation during combined treatment with split- course radiotherapy and chemotherapy in patients with head and neck cancer," Radiotherapy and Oncology, vol. 48, no. 2, pp. 157-164, 1998.

[36] G. Marsaglia and W. W. Tsang, "The ziggurat method for generating random variables," Journal of Statistical Software, vol. 5 , no. 8, pp. 1-7, 2000. 
[37] N. Wright and M. Alison, The Biology of Epithelial Cell Populations, vol. 2, Oxford Univerisy Press and Clarendon Press, Oxford, UK, 1984.

[38] E. Aarnaes, B. Kirkhus, and O. P. F. Clausen, "Mathematical model analysis of mouse epidermal cell kinetics measured by bivariate DNA/anti-bromodeoxyuridine flow cytometry and continuous $[3 \mathrm{H}]$-thymidine labelling," Cell and Tissue Kinetics, vol. 23, no. 5, pp. 409-424, 1990.

[39] C. S. Potten, "Cell cycles in cell hierarchies," International Journal of Radiation Biology \& Related Studies in Physics, vol. 49, no. 2, pp. 257-278, 1986.

[40] G. G. Steel, Basic Clinical Radiobiology, Hodder Arnold, UK, 2002.

[41] E. Lartigau, A. Lusinchi, P. Weeger et al., "Variations in tumour oxygen tension $\left(\mathrm{pO}_{2}\right)$ during accelerated radiotherapy of head and neck garcinoma," European Journal of Cancer, vol. 34, no. 6, pp. 856-861, 1998.

[42] J. M. Brown, "The hypoxic cell: a target for selective cancer therapy-eighteenth Bruce F. Cain Memorial Award Lecture," Cancer Research, vol. 59, no. 23, pp. 5863-5870, 1999.

[43] T. Alarcón, H. M. Byrne, and P. K. Maini, "A mathematical model of the effects of hypoxia on the cell-cycle of normal and cancer cells," Journal of Theoretical Biology, vol. 229, no. 3, pp. 395-411, 2004.

[44] A. S. E. Ljungkvist, J. Bussink, P. F. J. W. Rijken, J. H. A. M. Kaanders, A. J. van der Kogel, and J. Denekamp, "Vascular architecture, hypoxia, and proliferation in first-generation xenografts of human head-and-neck squamous cell carcinomas," International Journal of Radiation Oncology Biology Physics, vol. 54, no. 1, pp. 215-228, 2002.

[45] C. W. S. Chin, A. J. E. Foss, A. Stevens, and J. Lowe, "Differences in the vascular patterns of basal and squamous cell skin carcinomas explain their differences in clinical behaviour," Journal of Pathology, vol. 200, no. 3, pp. 308-313, 2003.

[46] R. E. Durand and E. Sham, "The lifetime of hypoxic human tumor cells," International Journal of Radiation Oncology Biology Physics, vol. 42, no. 4, pp. 711-715, 1998.

[47] A. S. E. Ljungkvist, J. Bussink, J. H. A. M. Kaanders et al., "Hypoxic cell turnover in different solid tumor lines," International Journal of Radiation Oncology Biology Physics, vol. 62, no. 4, pp. 1157-1168, 2005.

[48] L. Webster, R. J. Hodgkiss, and G. D. Wilson, "Cell cycle distribution of hypoxia and progression of hypoxic tumour cells in vivo," British Journal of Cancer, vol. 77, no. 2, pp. 227-234, 1998.

[49] J. P. Kirkpatrick, L. I. Cárdenas-Navia, and M. W. Dewhirst, "Predicting the effect of temporal variations in $\mathrm{PO}_{2}$ on tumor radiosensitivity," International Journal of Radiation Oncology Biology Physics, vol. 59, no. 3, pp. 822-833, 2004.

[50] J. Denekamp, A. Daşu, A. Waites, and B. Littbrand, "Hyperfractionation as an effective way of overcoming radioresistance," International Journal of Radiation Oncology Biology Physics, vol. 42, no. 4, pp. 705-709, 1998.

[51] A. Daşu and J. Denekamp, "Superfractionation as a potential hypoxic cell radiosensitizer: prediction of an optimum dose per fraction," International Journal of Radiation Oncology Biology Physics, vol. 43, no. 5, pp. 1083-1094, 1999.

[52] R. G. Dale and B. Jones, Radiobioloigcal Modelling in Radiation Oncology, The British Intistitue of Radiology, London, UK, 2007.

[53] K. R. Trott and J. Kummermehr, "Rapid repopulation in radiotherapy: a debate on mechanism. Accelerated repopulation in tumours and normal tissues," Radiotherapy and Oncology, vol. 22 , no. 3, pp. 159-160, 1991.
[54] J. Kummermehr, W. Dörr, and K. R. Trott, "Kinetics of accelerated repopulation in normal and malignant squamous epithelia during fractionated radiotherapy," BJR Supplement, vol. 24, pp. 193-199, 1992.

[55] C. H. J. Terhaard, H. B. Kal, and G. J. Hordijk, "Why to start the concomitant boost in accelerated radiotherapy for advanced laryngeal cancer in week 3," International Journal of Radiation Oncology Biology Physics, vol. 62, no. 1, pp. 62-69, 2005.

[56] M. Stuschke and H. D. Thames, "Hyperfractionated radiotherapy of human tumors: overview of the randomized clinical trials," International Journal of Radiation Oncology Biology Physics, vol. 37, no. 2, pp. 259-267, 1997.

[57] J. C. Horiot, A. C. Begg, R. Le Fur et al., "Present status of EORTC trials of hyperfractionated and accelerated radiotherapy on head and neck carcinoma," Recent Results in Cancer Research, vol. 134, pp. 111-119, 1994.

[58] E. J. Hall and A. G. Garcia, Radiobiology for the Radiologist, Lippincott Williams and Wilkins, Philadelphia, Pa, USA, 2006.

[59] C. S. Potten, "The cell kinetic mechanism for radiationinduced cellular depletion of epithelial tissue based on hierarchical differences in radiosensitivity," International Journal of Radiation Biology, vol. 40, no. 2, pp. 217-225, 1981.

[60] R. P. Hill, "Tumor progression: potential rolse of unstable genomic changes," Cancer and Metastasis Reviews, vol. 9, no. 2, pp. 137-147, 1990.

[61] J. A. Royds, S. K. Dower, E. E. Qwarnstrom, and C. E. Lewis, "Response of tumour cells to hypoxia: role of p53 and NFkB," Journal of Clinical Pathology, vol. 51, no. 2, pp. 55-61, 1998.

[62] E. Aarnaes, O. P. F. Clausen, B. Kirkhus, and P. De Angelis, "Heterogeneity in the mouse epidermal cell cycle analysed by computer simulations," Cell Proliferation, vol. 26, no. 3, pp. 205-219, 1993.

[63] C. I. Armpilia, R. G. Dale, and B. Jones, "Determination of the optimum dose per fraction in fractionated radiotherapy when there is delayed onset of tumour repopulation during treatment," British Journal of Radiology, vol. 77, no. 921, pp. 765-767, 2004.

[64] J. F. Fowler and P. M. Harari, "Confirmation of improved local-regional control with altered fractionation in head and neck cancer," International Journal of Radiation Oncology Biology Physics, vol. 48, no. 1, pp. 3-6, 2000.

[65] A. C. Begg, I. Hofland, and J. Kummermehr, "Tumour cell repopulation during fractionated radiotherapy: correlation between flow cytometric and radiobiological data in three murine tumours," European Journal of Cancer, vol. 27, no. 5, pp. 537-543, 1991.

[66] J. F. Fowler, "Rapid repopulation in radiotherapy: a debate on mechanism. The phantom of tumor treatment-continually rapid proliferation unmasked," Radiotherapy and Oncology, vol. 22, no. 3, pp. 156-158, 1991.

[67] W. Dörr, "Three A's of repopulation during fractionated irradiation of squamous epithelia: asymmetry loss, Acceleration of stem-cell divisions and Abortive divisions," International Journal of Radiation Biology, vol. 72, no. 6, pp. 635-643, 1997.

[68] D. D. Dionysiou, G. S. Stamatakos, D. Gintides, N. Uzunoglu, and K. Kyriaki, "Critical parameters determining standard radiotherapy treatment outcome for glioblastoma multiforme: a computer simulation," The Open Biomedical Engineering Journal, vol. 2, pp. 43-51, 2008. 


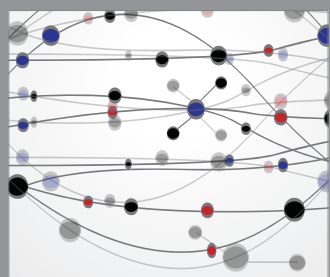

The Scientific World Journal
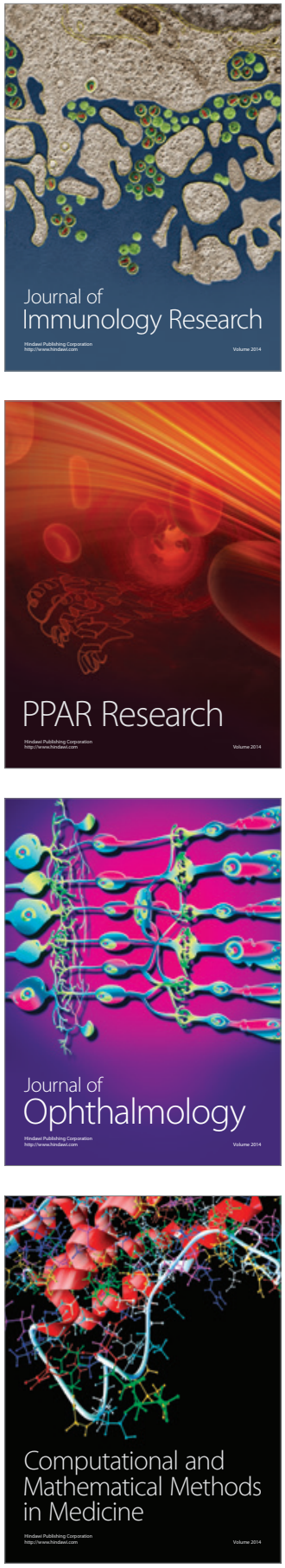

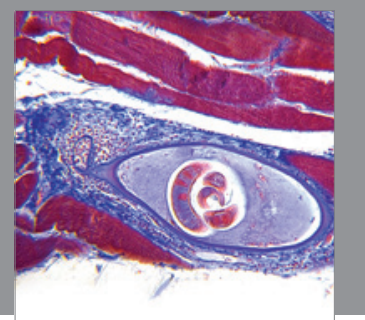

Gastroenterology

Research and Practice
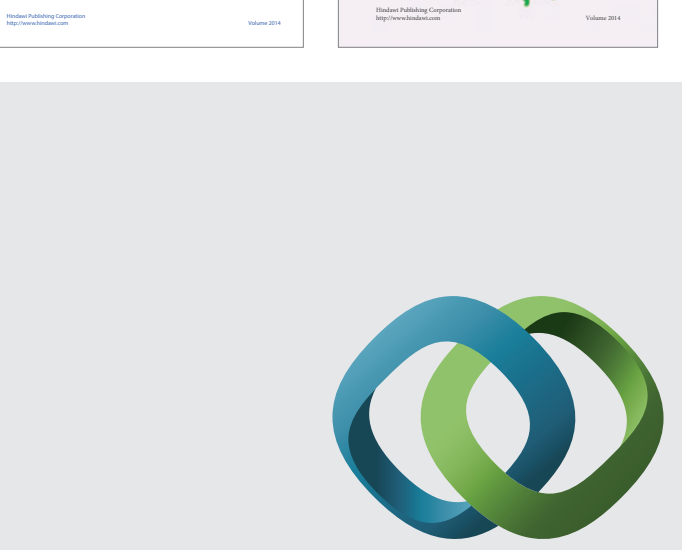

\section{Hindawi}

Submit your manuscripts at

http://www.hindawi.com
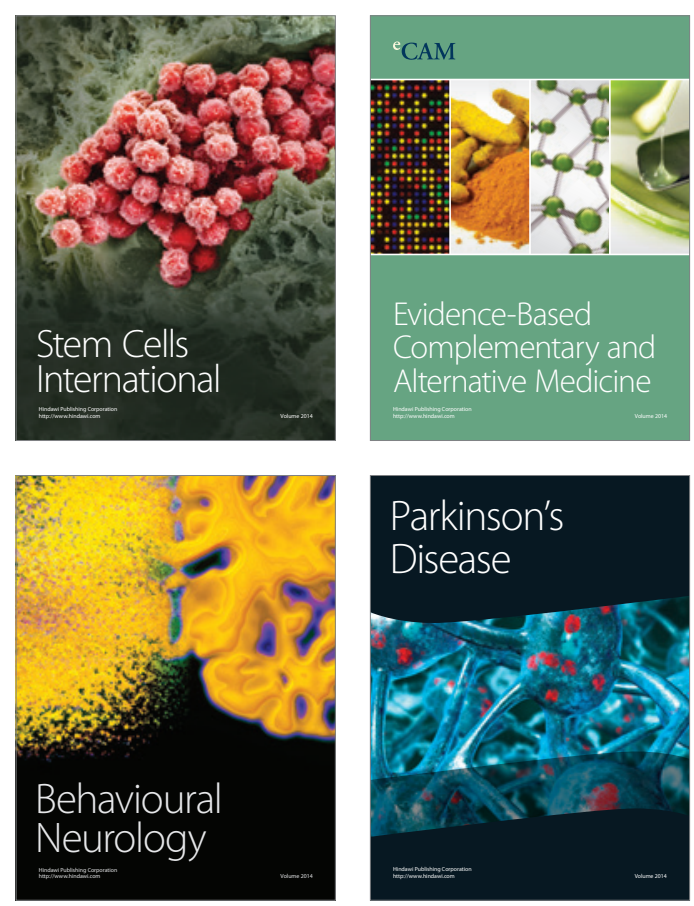

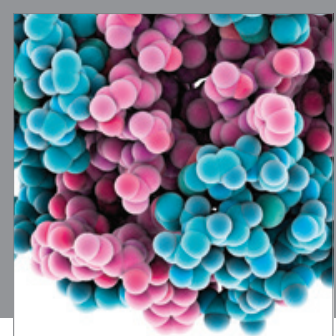

Journal of
Diabetes Research

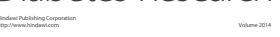

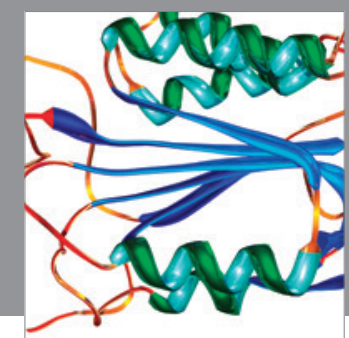

Disease Markers
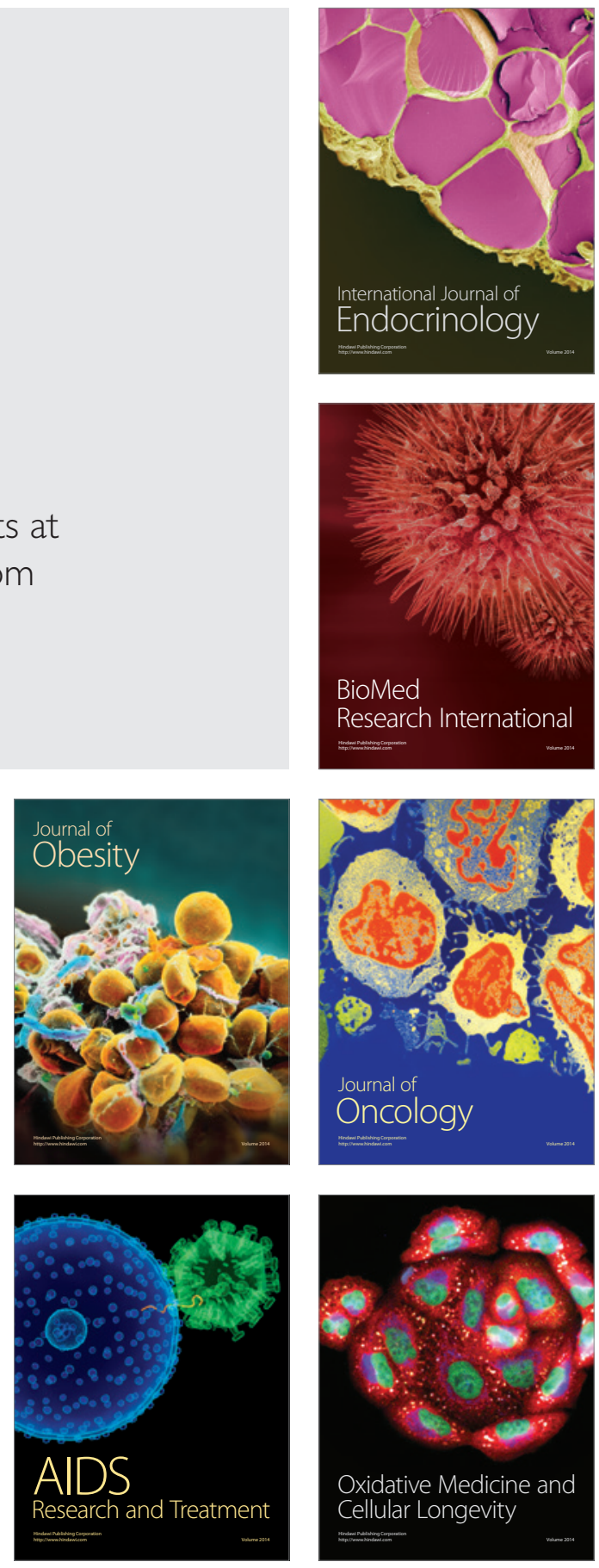